УДК: 355.41:616-036.21(497.11)

DOI: https://doi.org/10.18485/fb_covid19.2020.ch12

\title{
НЕКИ АСПЕКТИ ОТПОРНОСТИ И ФЛЕКСИБИЛНОСТИ ОДГОВОРА НАЦИОНАЛНЕ ЛОГИСТИКЕ НА КРИЗУ ИЗАЗВАНУ ПАНДЕМИЈОМ КОВИДА 19
}

проф. др Петар Станојевић 1

Апстракт: Кризне ситуације са собом носе много неодређености и неизвесности и захтевају брзу реакцију. Потпун и благовремен одговор на све проблеме, ризике и претње није могућ, али се могу смањити њихови негативни ефекти. У одговору на кризу подједнако су важни отпорност система (првенствено се схвата кроз постојање неопходних снага и средстава, односно ресурса) и његова флексибилност (могућност брзог прилагођавања). Ефективнији и ефикаснији одговор на појаве кризних ситуација постиже се кроз скуп припремних радњи које подразумевају проактивну припрему људских и материјалних ресурса, односно управљање превентивним активностима. У раду су анализирани аспекти одговора на кризу појединих логистичких функција. Наведени су и очити недостаци система националне логистике. Показало се да се Србија може снабдети основним животним потребама самостално. Припреме за кризне ситуације у Србији нису системске и свеобухватне. Истакнути су позитивни аспекти, који су првенствено везани за флексибилност и импровизацију. Флексибилност система је била на заводном нивоу и брзо су надокнађивани недостаци. Јасно се показало да Србија мора да се определи за повећање резерви и залиха као основног извора снабдевања у кризним ситуацијама. Када су одређени ресурси добијени, то је довело до промене стратегије. Дате су и препоруке којима би се управљање логистичком подршком у кризним ситуацијама у Србији могло побољшати, посебно у домену отпорности, али и флексибилности.

Кључне речи: кризна ситуација, национална логистика, логистичке функције, логистички ресурси, отпорност, еластичност

1 Универзитет у Београду, Факултет безбедности; e-mail: petstano45@gmail.com 


\section{Увод}

Логистика је реч која се користи да опише веома стару праксу снабдевања, кретања и дистрибуције робе, а у војном смислу још и одржавање опреме и збрињавање повређених и оболелих (задовољавање свих потреба) у миру и у борбеним условима. Овде би требало додати да се логистичке операције морају спроводити и у случају других, веома разнородних кризних ситуација као што су: индустријски акциденти, земљотреси, поплаве, еколошки акциденти, епидемије, пожари великих размера, мигрантске кризе (премештање становништва), већи терористички акти и још много тога другог. Сви случајеви који захтевају збрињавање повређених и оболелих, збрињавање и расељавање становништва (и животиња), довођење неопходног људства и доставу опреме, одржавање опреме, припрему и дистрибуцију хране и воде, неодложну изградњу или санацију неопходних зграда и инфраструктуре подразумевају ангажовање државних органа, међу којима војска свакако представља најопремљенију и најоспособљенију организацију. То су ситуације у којима треба да функционише „државна логистика“ или „национална логистика“, како је данас уобичајено рећи (придев „национални“ треба разумети као „државни“).

Националну логистику могуће је одредити кроз њен потенцијал, а то су ресурси и инфраструктура, а операционализација искоришћења тих ресурса и инфраструктура је привреда једне земље. Постоје и друге везе, као што је она да национална логистика омогућава земљи у финансијском смислу да развије заштитне системе од природних катастрофа. Међутим, ове две везе су на неки начин најважније2 2 .

Организације попут војске, полиције, цивилне заштите, ватрогасаца, безбедносних служби, здравственог система итд., главни су корисници националног логистичког система у случају ратова и осталих кризних ситуација. Задовољавање њихових потреба у Србији (или у било којој земљи у већим кризама/сукобима) немогуће је одвојити од задовољавања свих потреба становништва и привреде земље у кризним стањима. Из тог разлога потребно је при разматрању логистичких потенцијала укључити целокупну инфраструктуру и привреду, јер је она најпоузданији извор снабдевања.

Корени логистике су у националној привреди, где су доминантни утицаји цивилних власти ${ }^{3}$. У кризним стањима ресурси постају витални, јер није могуће дођи до нечег уколико нема одговарајуће сировине или технологије или није ускладиштено унапред у магацинима. Кључна важност сировина/ресурса и производних могућности издваја их као посебан фактор логистике у кризним ситуацијама, када је увоз на неки начин спречен. У овом случају неопходно је

\footnotetext{
2 Петар Станојевић, Василије Мишковић, Гордана Мишев, Национална логистика и безбедност, Универзитет у Београду - Факултет безбедности, Београд, 2017.

${ }^{3}$ Henry E. Eccles, Logistics in the National Defence. The Stackpole Co, Harrisburg, 1959.
} 
укључити и енергетику, јер без ње неће бити кретања, грејања, пољопривредних радова, спремања хране, прања и много тога другог од чега зависи функционисање у данашње време.

Хитна (Emergency) логистика (логистика ванредних ситуација или хуманитарна логистика) је термин који се користи од стране логистике, ланца снабдевања и производне индустрије да означи одређене временски критичне активности које су нужне за кретање робе или опреме у хитним случајевима. Разлог за мобилизацију хитних логистичких услуга може да буде кашњење или хитна потреба за специјализованом опремом за спречавање догађаја као што су нежељено слетање авиона, заустављање бродова или прекид комуникација. Хуманитарна логистика укључује владе, војске, хуманитарне агенције, донаторе, невладине организације и хитне логистичке услуге које обично потичу од специјализованих провајдера који укључују војску и полицију4.

Данас се сматра да је логистика наука о пружању подршке операцијама које могу бити у најразличитијим областима: производња, продаја, опслуга, сервисирање, здравствена заштита, образовање, спасавање у катастрофама, подршка војним операцијама итд. Стварну подршку пружа логистички систем који се успоставља управо за тај случај. У сваком посебном случају постоји основна делатност којој је, да би се могла реализовати, потребна одговарајућа подршка. Ту подршку пружа управо логистички систем. Логистичка подршка се реализује кроз остваривање логистичких функција (делатности), а оне представљају појединачне интегрисане активности логистичке подршке које обављају за то посебно структурирани подсистеми у структури система логистичке подршке 5 . Дакле, функције су скуп активности које су на одређен начин интегрисане, реализују их подсистеми система логистичке подршке који су управо за то и пројектовани и устројени. Нпр. функција је исхрана, а спроводи је интендантска служба као подсистем војске или прецизније војне логистике.

У конкретном случају, кад се ради о логистичкој подршци конкретне операције, активности или задатка, мора се сагледати које то логистичке функције (делатности) морају бити реализоване. То је управо случај и код конкретног случаја пандемије ковида 19 , коју можемо слободно разматрати као логистичку операцију. Када се ради о логистичкој подршци конкретне операције, не морају бити реализоване све функције које конкретни систем логистичке подршке иначе може да реализује. Реализују се само оне активности којима се задовољавају захтеви који се постављају пред конкретни систем логистичке подршке ангажовањем потребних ресурса самог система 6 .

\footnotetext{
${ }^{4}$ Петар Станојевић, Василије Мишковић, Гордана Мишев, Национална логистика и безбедност, ор. cit.

5 Ibid.

${ }^{6}$ Ibid.
} 


\section{ПРОИЗВОДИ И УСЛУГЕ ОД ПОСЕБНОГ ЗНАЧАЈА}

Епидемије и пандемије заразних болести су апострофирани у Стратегији националне безбедности као изазов, ризик и претња7. За случај епидемије ковида 19 интересантно је да је одлуком о одређивању производа и услуга од посебног значаја за одбрану Републике Србије апострофирано и следеће8:

- „логорска опрема, војна униформа, теренска обућа и друга лична опрема, специјална, заштитно-радна и радна одећа опште намене и опрема за радне животиње;

- потрошни материјал за одржавање личне и колективне хигијене и за прање и хемијско чишћење;

- пшеница, кукуруз, кукурузни гриз и брашно, квасац за производњу хлеба, хлеб, тестенине, пиринач, пасуљ, воће и поврће, производи од воћа и поврћа, месо и риба, производи од меса и рибе, млеко и производи од млека, шећер, со, маст, уље, вода, цигарете, шибице, сојина сачма и остала храна за домаће животиње, семенски и садни материјал пољопривредног биља и семе за вештачко осемењавање домаћих животиња;

- лекови, помоћна лековита средства, медицинска средства, медицинска опрема и санитетски комплети;

- ветеринарски комплети, биолошка средства, лабораторијске хемикалије, готови лекови, средства за дезинфекцију, дезинсекцију и дератизацију, завоји, хируршки шиваћи материјал, инструменти и средства за преглед стоке за клање, поткивачка опрема и прибор за животиње итд.

- извршавање мера превентивно-медицинске заштите; лечење повређених и оболелих лица; производња, израда и снабдевање лековима и помоћним лековитим средствима, медицинским средствима, медицинском опремом и санитетским комплетима и вршење лабораторијских експертиза и прикупљање крви од добровољних давалаца;

- преглед и лечење животиња, ветеринарско-санитарни преглед, дијагностичка испитивања и лабораторијске услуге, дезинфекција, дезинсекција и дератизација, контрола и заштита пољопривредног биља.

Практично је побројано све оно што је било критично у разматраној ситуацији кризе изазване епидемијом ковида 19. Очекивало би се да постоје планови о количини потребних наведених производа и услуга у случајевима могућих сценарија кризних ситуација. Такође, очекивало би се да постоје припремљени

7 „Стратегија националне безбедности Републике Србије (2019)“ Службени гласник РС, бр. 94/2019, Београд, 27. децембар 2019.

8 „Одлука о одређивању производа и услуга од посебног значаја за одбрану Републике Србије (2019)“, Службени гласник РС, бр. 58/2008и бр. 26/2019, Београд, 6. јун 2008. и 5. април 2019. 
људски ресурси, материјал и опрема у довољним количинама према плановима. Материјал и опрема би требало да буду на залихама или да постоје технолошки ресурси са довољним капацитетом да се исти у случају потребе произведу. Претходно наведено представља идеалан случај. Са кризама би се било лако борити да је све увек идеално, али по правилу није.

\section{ЛОГИСТИЧКЕ ФУНКЦИЈЕ У ЕПИДЕМИЈИ КОВИДА 19}

Структура приказане анализе је таква да тематски прати првенствено логистичке, али и друге повезане службе оружаних снага9 свеобухватно и наменски сагледавају могућност и ресурси за деловање у кризним ситуацијама. Војна логистика као систем је најкомплекснија, па је зато одабрана као костур анализе.

Логистичка подршка Војске Србије дефинисана је чланом 45. Закона о одбрани10. „Логистичка подршка Војске Србије реализује се ради задовољавања оперативних потреба Војске Србије у:

1) одржавању наоружања и војне опреме;

2) снабдевању наоружањем и војном опремом и другим средствима;

3) општим логистичким потребама;

4) планирању, изградњи, рушењу, уклањању и одржавању објеката инфраструктуре;

5) саобраћају и транспорту људи и средстава;

6) здравственој заштити;

7) ветеринарској заштити;

8) безбедности и здрављу на раду;

9) заштити животне средине;

10) заштити од пожара и експлозија;

11) ловно-шумској делатности;

12) другим логистичким делатностима од значаја за одбрану и Војску Србије. Логистичку подршку обављају установе и јединице Војске Србије.“

Даље излагање има за циљ да пружи информације о актуелној ситуацији и чињеницама одговора на актуелну пандемију ковида 19. Дакле, оквир

9 Службе у Војсци Србије се дела на опште и логистичке. Опште службе су: кадровска, телекомуникације, обавештајна, безбедносна, информатичка, атомско-биолошкохемијска, ваздушно осматрање и јављање, геодетска, правна, финансијска метеоролошка и навигацијска служба. Логистичке службе су: техничка, интендантска, санитетска, саобраћајна, ветеринарска и грађевинска служба.

10 „Закон о одбрани Републике Србије (2018)“Службени гласник РС, бр. 36/2018, Београд, 10. мај 2018. 
разматрања се односи на разумевање српског националног логистичког система у стању „какав јесте“, и „како је реаговао у конкретној операцији“. Више о стању и перспективама националне логистике у Србији се може прочитати у литератури ${ }^{11 .}$

\section{Новчани - финансијски ресурси ${ }^{12}$}

Новчани ресурси представљају једну од кључних полуга за успешно превазилажење кризе. Неминовно се морају платити разне врсте законом предвиђених накнада, набавити различити материјали из земље и иностранства, дати олакшице и подстицаји, повећати плате и дати разне врсте помоћи, а све то у условима смањеног прилива новца у буџет.

За регулисање ове области у току ванредног стања донето је 19 уредби, одлука и правилника (неће се наводити сви појединачно). Њима се регулисала стабилност финансијског система, лизинг, употреба буџетске резерве, емисија државних записа, накнаде, плате, новчане помоћи, порези, фискалне погодности, додатно државно задуживање и коришћење средстава из буџета.

Већ годинама је буџет Србије у висини од око 9-10 милијарди евра. Буџет за $2020^{13}$. годину предвиђао је највеће приходе од ПДВ-а, више око 44\%, затим од акциза око $23,6 \%$, пореза на добит око 8\%, пореза на доходак око $5 \%$ и царина $4 \%$. Већи део буџета је оријентисан социјално, а мањи део је развојно-пројектно усмерен. Из претходног је јасно да је буџет веома осетљив на пад привредне активности.

За попуну ратних материјалних резерви било је предвиђено 240.000.000 динара, за цивилну одбрану 13.500 .000 , за ванредне ситуације 13.500 .000 , за подизање логистичког специјално-техничког капацитета организационих јединица Министарства унутрашњих послова 350.000 .000 , за робне резерве 2.755 .000 .000 и за управљање обавезним резервама (резерве нафте и деривата нафте) 4.647.290.000. Текућа буџетска резерва је предвиђена у износу од 3.000.000.000 динара. Из претходног се види да се највише средстава за материјалне залихе опредељује за нафту и деривате на основу међународно преузетих обавеза у сагласности са директивом E3 119/2009. Износи за стварање других врста материјалних резерви су око 250 милиона евра годишње, што није занемарљив

11 Petar Stanojević, Vasilije Mišković, Zoran Jeftić, “Overview of elements of national logistics system in the republic of Serbia”, Vojno delo, Vol. 69, No. 4, 2017, pp. $96-120$.

12 За ово је одговорна финансијска служба.

13 „Закон о буџету Републике Србије за 2020. годину (2020)”, Службени гласник РC, бр. $84 / 2019$ и $60 / 2020$, Београд, 24. април 2020. 
износ. На почетку кризе држава је имала 168,2 милијарде динара на рачуну14. Држава се показала ликвидна, стабилна, о чему говори чињеница да је имала довољно новца за исплату плата и пензија. Део новца дониран је из ЕУ - 93 милиона евра и из Норвешке - 5 милиона. На самом почетку ванредног стања постојала је појачана тражња за готовином, слично као за робом из продавница. Банке и НБС имале су новца у довољној количини, а курс је био стабилан.

Држава је 21. марта донела одлуку да позајми од домаћих и међународних комерцијалних и мултилатералних финансијских институција и иностраних влада износ од највише 50.600.000.000 динара, а да се кроз емитовање државних хартија од вредности (државних записа и обвезница на домаћем финансијском тржишту у домаћој и страној валути) задужи у износу од највише 312.000.000.00015.

Уредбом о коришћењу финансијских средстава буџета Србије за време ванредног стања која је донета и објављена 20. марта за време ванредног стања могле су се без ограничења преусмеравати апропријације предвиђене за другу намену у текућу буџетску резерву. Оне су се могле користити за ублажавање последица. Овим је постигнута значајна оперативна флексибилност буџетског система финансирања ${ }^{16}$.

Дужи низ година државне девизне резерве су на нивоу 9-12 милијарди евра, зависно од политике Народне банке у појединим периодима. Део је у власништву Народне банке, а мањи део су обавезни депозити банака. Највећи део овог новца чува се на рачунима страних банака или у виду обвезница страних држава, или како се наводи „у сигурним пласманима“. Мањи део се чува у злату (око 5\%), готовини или на други начин. Сматра се да би ове резерве требало да обезбеђују покривеност новчане масе за више од $200 \%$ и шест месеци увоза робе и услуга.

Бруто девизне резерве Народне банке Србије износиле су на крају априла 2020. године 12,79 милијарди евра и биле су ниже су за 321,7 милиона евра у односу на март, углавном због интервенција на очувању курса. Вредност динара је остала готово непромењена у односу на евро. Девизним резервама на овом нивоу могуће је обезбедити покривеност новчане масе од $154 \%$ и више од пет месеци увоза

14 М.А, „Мали:Апсолутно смо ликвидни, НЕМА ПРОБЛЕМА за плате и пензије“,Блиц, 12.03.2020, https://www.blic.rs/biznis/vesti/mali-apsolutno-smo-likvidni-nema-problemaza-plate-i-penzije/g26dk96, 24/08/2020.

15 „Одлука о емисији дугорочних државних хартија од вредности, 05 број 424-2753/2020“, Службени гласник РС, бр. 39/2020, Београд, 21. март 2020.

16 „Уредба о коришћењу финансијских средстава буџета Републике Србије за време ванредног стања насталог услед болести цовид-19 изазване вирусом Сарс-Цов-2 (2020)“, Службени гласник РC, бр. 38/2020, Београд, 21. март 2020. 
робе и услуга. У поседу НБС било је 10,67 милијарди евра, а остатак су били депозити банака ${ }^{17}$.

Народна банка Србије је на седници 7. маја утврдила листу банака у Србији које су системски значајне и стопе заштитног слоја капитала за те банке. На тој листи су се нашле банка Поштанска штедионица, Интеза, Комерцијална, ОТП, Војвођанска, Рајфајзен, АИК и Ерсте банка. Системски значајна банка је она чије би погоршање финансијског стања или престанак рада имали озбиљне негативне последице на стабилност финансијског система Србије 18.

Штедња становништва је остала на нивоу од 8-9 милијарди евра. То практично значи да сваки грађанин Србије има уштеђених нешто више од 1.200 евра у просеку. Истовремено, кредитна задуженост грађана је једна од најнижих у Европи ${ }^{19}$.

Већ на почетку пандемије инвеститори су повукли 83 милијарде америчких долара са тржишта земаља у развоју 20 . На овај начин пољуљана је теорија о развоју само на бази привлачења страних директних инвестиција, а истовремено се отворило питање сигурности, а можда још више и доступности свих новчаних депозита једне земље ван њених граница, посебно имајући у виду исказане тенденције затварања свих земаља у сопствене оквире. С тим у вези је питање на колики део новца Народне банке Србије може да се рачуна у кризној ситуацији, јер се највећи део овог новца чува на рачунима страних банака или у виду обвезница страних држава (више од две трећине), или како се наводи „у сигурним пласманима“. Мањи део се чува у злату (око 5\%), готовини или на други начин. Треба имати у виду да евентуална немогућност да се „покрије новчана маса“ може за последицу имати драстично смањење вредности домаће валуте, што је више пута виђен сценарио деведесетих година. Вероватно би требало размотрити колики је то минимум новца који мора бити на располагању у земљи (нпр. резерве које обезбеђују покривеност новчане масе за $100 \%$ и три месеци увоза робе и услуга). Овога пута није било потребе за додатним опорезивањем, као што је учињено 1999. године (уведен је додатни ПДВ од 3\%).

17 „Девизне резерве Србије 12,79 милијарди евра на крају априла“, Политика, 14. мај .2020, http://www.politika.rs/sr/clanak/454131/Devizne-rezerve-Srbije-12-79-milijardievra-na-kraju-aprila, 25/08/2020.

18 Озрен Милановић, „Нова листа системски значајних банака“, Политика, 17.05.2020, http://www.politika.rs/sr/clanak/454296/Nova-lista-sistemski-znacajnih-banaka, 25/08/2020.

19 Петар Станојевић, Василије Мишковић, Гордана Мишев, Национална логистика и безбедност, ор. cit.

20 Небојша Поповић, „Корона показала зашто економском моделу Црне Горе истиче рок трајања“, Спутњик 04. април 2020, https://rs.sputniknews.com/regioni/202004041122243909-korona-pokazala-zastoekonomskom-modelu-crne-gore-istice-rok-trajanja-/, 25/08/2020. 


\section{Људски ресурси ${ }^{21}$}

Према резултатима пописа из 2011. године број мушкараца који спадају у статистичку групу „Оптимални фертилни (20-34)“ (некада I позив) био је 673.822 или 9,45\% од укупног становништва, а у групи „Фертилни (15-49)“ (или практично I и II позив) је 1.582.643 или $22,19 \%$ становништва 22.

Узевши као претпоставку да би „под заставу“ (у војску) у случају опште мобилизације у садашњим околностима било позвано до 100.000 људи $^{23}$ и у полицију до 50.000, могло би се закључити да расположивог људства за потребе цивилне одбране и радне обавезе има у изобиљу (више од $75 \%$ од укупно од расположивих), односно да људства има довољно за све одбрамбене и безбедносне потребе.

Готово да нема земље која током пандемије није ангажовала војску. Неке су извршиле делимичне мобилизације, попут Русије и Казахстана.

Према писању Политике 24 припадници војске су обезбеђивали 17 прихватних и центара за азил, 149 социјалних установа за одрасла и стара лица, 18 граничних прелаза и 40 здравствених центара у 20 градова. Војска Србије уредила је привремену болницу за смештај лица са лакшом клиничком сликом обољења од ковида 19 на Београдском сајму, где је обезбеђено 3.000 кревета, уређене су привремене болнице и на Новосадском сајму и у нишкој хали Чаир, а Војномедицински центар на Карабурми претворен је у привремену болницу са 100 лежаја. Војна болница у Новом Саду била је спремна за пријем и лечење 100 теже оболелих пацијената. Војска Србије је обезбеђивала смештај, исхрану и спољње обезбеђење у објектима за здравствени надзор за грађане који су долазили из иностранства у Моровићу, Суботици и Летенки код Новог Сада, а за још 11 објеката за здравствени надзор пружала је само обезбеђење. Јединица АБХО из Крушевца је била ангажована на пословима дезинфекције (деконтаминације).

у Србији се од првог дана појавила потреба за волонтерима за обављање различитих послова, од снабдевања грађана старијих од 65 година, рада у медицинским установама, до ангажовања пензионисаних војних лекара.

21 Одговорност је кадровске службе.

22 Петар Станојевић, Василије Мишковић, Гордана Мишев, Национална логистика и безбедност, ор. cit.

23 "Serbia Military Strength (2020)", Global Firepower Index, https://www.globalfirepower.com/country-military-strength-detail.asp?country_id=Serbia, 26/08/2020.

24 Милан Галовић, „Војни резервисти у борби против ковида 19“, Политика, 03. април .2020, http://www.politika.rs/scc/clanak/451490/Vojni-rezervisti-u-borbi-protiv-kovida-19, 26/08/2020. 
Према доступним домаћим изворима у јединице радне обавезе позвано је 30 лица у Новом Саду и 30 у Београду искључиво за обављање немедицинских послова ${ }^{25}$, и то оних који су војни рок одслужили цивилно у домовима здравља. Првенствено су били ангажовани они који немају радно ангажовање.

Већ на самом почетку видело се да Србија нема припремљене јединице цивилне заштите и радне обавезе за овакве ситуације и поред релативног изобиља у људству. Зато се морало прибећи вансистемским решењима попут позивања волонтера, уместо да су ангажоване већ спремне јединице. Јединице, посебно радне обавезе, не захтевају ни посебну обуку ни опрему, па је нејасно због чега нису биле формиране. Слична ситуација била је и током поплава 2014. године.

Потврда да је ситуација далеко од идеалне стигла је у виду одговора Министарства одбране Политици ${ }^{26}$. У њему се наводи: „И у наредном периоду, на основу захтева Сектора за ванредне ситуације МУП-а, центри Министарства одбране за локалну самоуправу наставиће да врше попуну јединица цивилне заштите људством, као и покретним и непокретним стварима посебне намене. Очекује се додатна ангажованост територијалних органа Министарства одбране, пре свега у виду пружању стручних објашњења и подршке јединицама локалне самоуправе како би се успешно извршило формирање и попуна јединица цивилне заштите опште намене, али и специјализованих јединице цивилне заштите за узбуњивање која ће из надлежности МУП-а прећи у надлежност градова и општина“. Из наведеног би се могло закључити да су јединице цивилне заштите и радне обавезе у фази формирања.

„Обука и припрема становништва су такође запуштени. Тек од пре две године, односно након 28 година од укидања предмета Општенародна одбрана и друштвена самозаштита, у средњошколске клупе ученика завршних разреда, дакле, пунолетних особа, вратила се настава о основама система одбране Републике Србије кроз факултативно спровођење. Одељењским старешинама у извођењу наставе стручну помоћ пружају и припадници Министарства одбране и Војске Србије, као и резервне војне старешине“27.

Овде, међутим, не треба сметнути с ума да према члану 91. Закона о војној, радној и материјалној обавези јединице радне обавезе се ангажују само у условима ванредног и ратног стања ${ }^{28}$ и да у другим случајевима њихово ангажовање није

25 Ibid.

26 Милан Галовић, “Повратак народне одбране“, Политика, 23. март .2020, http://www.politika.rs/sr/clanak/450604/\%D0\%9F\%D0\%BE\%D0\%B2\%D1\%80\%D0\%B0 $\% \mathrm{D} 1 \% 82 \% \mathrm{D} 0 \% \mathrm{~B} 0 \% \mathrm{D} 0 \% \mathrm{BA}-$

\%D0\%BD\%D0\%B0\%D1\%80\%D0\%BE\%D0\%B4\%D0\%BD\%D0\%B5-

\%D0\%BE\%D0\%B4\%D0\%B1\%D1\%80\%D0\%B0\%D0\%BD\%D0\%B5, 26/08/2020.

27 Ibid.

28 “Закон о војној, радној и материјалној обавези (2018)“, Службени гласник РС, бр. 88/2009, 95/2010 и 36/2018, Београд, 10. мај 2018. 
могуће, односно у овом случају њихово масовно ангажовање није било могуће, већ на нивоу позваних појединаца, што је свакако регулативни недостатак.

Као извор људства обученог за већину послова из области одбране и безбедности, не би требало заборавити привредна друштва која се баве приватним обезбеђењем. Према подацима Привредне коморе Србије тренутно се овим пословима бави 314 компанија са око 27.000 запослених. Ове организације могу послужити као значајан извор људства, извор информација, али и самостално или у координацији могу обављати одређене безбедносне задатке. Бројеви се иначе значајно разликују у различитим изворима. По неким изворима у овом сектору ради између 40 и 60.000 људи, од којих 50\% ради „на црно“29.

У суседној Хрватској поучени искуствима изјављују: „Даље ћемо покушавати да проширимо Цивилну заштиту и инсистираћемо и даље на увођењу обавезног војног рока, јер је ово показало да су нам кључни клинци од 18 до 30 година. Војни рок на четири месеца, по швајцарском моделу, исто за жене и мушкарце“, казао је Калинић, како преноси Танјуг ${ }^{30}$.

Калинић је рекао да су Хрвати нација са мало људи и да је обавезни рок једино решење да би у кризним ситуацијама могло адекватно да се реагује. Вероватно је да Србија мора озбиљно да размотри исте предлоге. У Србији можда број људи није проблем, али се свест, информисаност, обученост, однос према личној и колективној безбедности, разумевање хијерархије, процедуре и дисциплина свакако морају унапредити.

\section{Интелектуални ресурси 31}

Када се посматра по струкама од посебног значаја за војнобезбедносни сектор, у Србији има око 20.000 инжењера са лиценцама (према подацима Инжењерске коморе Србије) и приближно исто лекара. Процена је да се годишње на студије упише око 5.500 студената ИТ технологија.

Тренутно у Србији ради око 12.000 научника и истраживача. Процењује се да је 30.000 српских научника и истраживача у дијаспори. Треба напоменути да Србија данас има готово 11.000 универзитетских наставника и око 5.000 сарадника у настави који тренутно школују око 240.000 студената, од којих око 100.000 на буџету (око 30.000 дипломира годишње са државних и око 7.000 са приватних

\footnotetext{
29 Петар Станојевић, Василије Мишковић, Гордана Мишев, Национална логистика и безбедност, ор. cit.

30 „У Хрватској обавезни војни рок по швајцарском моделу?“ Политика, 17. април .2020, http://www.politika.rs/scc/clanak/452436/U-Hrvatskoj-obavezni-vojni-rok-po-svajcarskommodelu, 27/08/2020.

31 Одговорност је кадровске службе.
} 
универзитета). Наводно трећина инжењера оде у свет чим дипломира, а у дијаспори ради око 10.000 наших лекара ${ }^{32}$.

Дванаест научних института (из области природних и математичких наука) покривају области: нуклеарних наука, физике, хемије, медицине, вакцина и серума, биологије, генетике и мултидисциплинарних истраживања. Поред ових постоји 17 института из области друштвено-хуманистичких наука који поред осталог изучавају проблеме из области: економије, економике пољопривреде, међународне политике и привреде, као и криминологије 33 .

У Србији постоји један истраживачко-развојни институт из области природноматематичких наука, 11 из области техничко-технолошких наука и 16 из области биотехничких наука. Техничко-технолошке науке покривају области нуклеарних технологија, електротехнике, електронике и телекомуникација, науке о материјалима, водопривреде, архитектуре и урбанизма, и тек два везана за компаније, нека подручја у машинству и један за област рударства и металургије. Институти из области биотехничких наука покривају све области пољопривреде и шумарства ${ }^{34}$.

Када се на број од око 12.000 научника и истраживача запослених у институтима додају подаци о бројевима истраживача и инжењера у великим пројектним предузећима (институтима) попут Енергопројекта или Војнотехничког института и оних са универзитета, бројка вероватно премашује 40.000 људи који могу учествовати у креативном решавању проблема које намећу кризне ситуације 35 .

Резултати овог ресурса за време пандемије су били више него запажени. Србија је произвела сопствени респиратор. Заслуга за овај посао припада компанији „Смарт Рисрч“ и Институту Михајло Пупин, који су направили пет прототипских уређаја за механичку вентилацију плућа - респиратора који ће бити употребљиви након добијања свих потребних лиценци ${ }^{36}$. Институт за примену нуклеарне енергије развио је серолошке тестове за коронавирус. Институт ће стандардизовати производњу тестова који ће да утврди, да ли је организам тренутно изложен или jе некад био изложен вирусу SARS-Cov-2. Тест би требало да буде ефикасан чак и у

32 Петар Станојевић, Василије Мишковић, Гордана Мишев, Национална логистика и безбедност, ор. cit.

33 Ibid.

34 Ibid.

35 Ibid.

36 Марко Николић, „Српски хероји направили респиратор вреднији од злата“, Спутњик, 24. мај .2020, https://rs.sputniknews.com/radio_tehnogram/202005241122640224-srpskiheroji-napravili-respirator-vredniji-od-zlata-video/, 27/08/2020. 
случају да вирус мутира ${ }^{37}$. Овде треба додати и опремање и прилагођавање две у суштини пољопривредне лабораторије за анализу тестова на вирус.

Фонд за иновациону делатност одобрио је 53 милиона динара за финансирање 12 иновативних пројеката предузећа чији је циљ сузбијање ефеката пандемије изазване коронавирусом. У кратком периоду биће развијено и доступно за коришћење 12 решења, попут већ споменутог респиратора, нове врсте заштитне маске са измењивим НЕРА филтером за вишеструку и дугорочну употребу, кабине за дезинфекцију која је намењена употреби на јавним местима и локацијама од интереса, мобилног пулта за бесконтактно мерење температуре и ручну дезинфекцију, преносиви озонизатори за брзу и безбедну дезинфекцију објеката од критичног значаја итд ${ }^{38}$.

\section{Набавке и помоћ}

Први авиони са помоћи за Србију су стигли из Кине. Кина је помогла у тренутку када је постојао проблем са набавкама и допремом опреме. Из Кине је стигла заштитна опрема, две машине за производњу заштитних маски и одела, две модерне лабораторије за коронавирус капацитета 3.000 тестова дневно. Кина је поклонила 100 клиничких респиратора.

Помоћ у материјалу Србији стига је и из Уједињених Арапских Емирата крајем марта (око 10т) са заштитним оделима, болничким оделима, рукавицама, заштитом за ципеле, маскама, санитизерима и сл.

Укупно 11 авиона слетело је на батајнички аеродром носећи помоћ из Руске Федерације. Из Москве је стигла помоћ у заштитној опреми, али и машинама за дезинфекцију отворених простора. Руско Министарство одбране послало је 87 војних вирусолога и лекара, специјалну опрему и технику, укључујући заштитна средства и 16 јединица војне технике. Из Турске су стигле маске, одела и тестови, као и из Мађарске.

Путовања људи су била практично обустављена, док је транспорт робе текао несметано. Помоћ је пристизала авионима. Две Владине уредбе које регулишу проток саобраћаја и неопходну документацију су донете током ванредног стања.

37 "Успех Српских научника: Направили тест на корону, ради чак и ако ВИРУС МУТИРА“. Блиц, 12. мај .2020, https://www.blic.rs/vesti/drustvo/uspeh-srpskih-naucnika-napravilitest-na-koronu-radi-cak-i-ako-virus-mutira/7m5mzdm, 27/08/2020.

38 „Представљени резултати јавног позива за сузбијање ефеката пандемије COVID-19“, Фонд за иновациону делатност Републике Србије, 18. мај 2020, http://www.inovacionifond.rs/info/predstavljeni-rezultati-javnog-poziva-za-suzbijanjeefekata-pandemije-covid-19, 27/08/2020. 
Набавке су се углавном одвијале по упрошћеним процедурама (рестриктивни поступак) у складу са члановима 7, 36, 131, 131a, 131б, 1316, 131e, Закона о јавним набавкама39 јер се захтевала хитност у поступању.

\section{Снабдевање храном}

Србија се према површини обрадивог земљишта по становнику налази на 17. месту међу 206 земаља и територија са 0,48 хектара, што је више него двоструко више од светског просека. Рачуна се да је за прехрамбену самоодрживост становништва потребно 0,2 хектара по становнику. С обзиром на то да има више него два пута обрадивих површина него што је потребно по становнику, као и на повољне климатске и друге факторе, Србија би требало да може да задовољи своје потребе у храни у потпуности 40.

Током ванредног стања донето је пет уредби којима се регулише ова област. Оне су се тицале забране извоза основних производа битних за становништво, висине цена основних и животних намирница и премија за млеко.

Привредна комора је све време пратила кретање на тржишту и прикупљала податке из 11 највећих трговинских ланаца. За викенд 14. и 15. марта, који је претходио увођењу ванредних мера, забележен је највећи раст тражње у свим категоријама основних животних намирница - брашна за чак 463,2\%, соли 412\%, рибљих конзерви $324,2 \%$ одсто, тестенина 285,5\%, уља 264\%. Потражња је била велика посебно за намирницама продуженог рока трајања, што се приписује психолошком ефекту стварања залиха у домаћинствима. Нешто мањи је био скок тражње за шећером 19,2\%, свежом рибом 14,4\%, сољу 9,7\%, јајима 9,1\% и свежим месом 8,4\%. Скокови тражње нису били само на почетку кризе, тако је нпр. у четвртак 7. маја, дошло је до раста тражње за тестенином 85,2\%, уљем и детерџентима. ${ }^{41}$ у Данској је на интересантан начин решено стварање непотребних залиха. Тамо су за једно паковање средства за дезинфекцију наплаћивали 5,5 евра, а цена за два комада је била 134 евра ${ }^{42}$. Креирањем одговарајућих прописа ова идеја се може применити и код нас.

39 „Закон о јавним набавкама (2015)“, Службени гласник РС, бр. 68/2015, Београд, 04. август 2015.

40 Петар Станојевић, Василије Мишковић, Гордана Мишев, Национална логистика и безбедност, ор. cit.

41 Подаци Привредне коморе које преноси портал InfoBiz. Видети: „Овако су Срби куповали први и последњи дан ванредног стања, само за једном намирницом скок 500\%“, InfoBiz, 09. мај 2020, https://biznis.telegraf.rs/info-biz/3187674-neverovatne-cifreovako-su-srbi-kupovali-prvi-i-poslednji-dan-vanrednog-stanja, 29/08/2020.

42 „У Данској средство за дезинфекцију 5,5 евра, цена за два комада - 134 евра“, N1, 21.03.2020, http://rs.n1info.com/Lifestyle/a580493/U-Danskoj-sredstvo-za-dezinfekciju-5-5evra-cena-za-dva-komada-134-evra.html, 29/08/2020. 
Уочи и на почетку ванредног стања знатно је била повећана потражња, да би се стабилизовала већ од 30. марта. Залиха основних намирница је било довољно. Прво је забрањен, па дозвољен извоз брашна. Воћа је било довољно. Јабука је било у резерви. Увозили смо велике количине поврћа и поред велике домаће производње. До евентуалних проблема је могло да дође са снабдевеношћу јужним воћем да је Турска затворила границе43. Највећи проблеми били су са недостатком паковања од 1 кг брашна и регулисањем кретања пољопривредника који су морали да обављају радове. Нађено је решење да се пољопривредницима дозвољава кретање на тракторима.

\section{Индустријска производња}

Обнављање производње квасца у Србији симбол је процеса који ће неумитно захватити све земље после пандемије короне, а то је јачање одређених стратешких сектора привреде и „минимум самодовољности“.

Квасац је производ кога није било довољно ни у кризи изазваној короном 19, нити када су уведене санкције 1990-тих. Квасац се увозио из Мађарске и Хрватске. Компанија Биоспрингер РС у Сенти почела је производњу квасца пуним капацитетом у понедељак, 23. марта, а продукција у малим паковањима је била увећана чак 450\%, а у паковањима од 500 грама за пекаре - за 100\%. План је био да се достигне месечна производња од 900 тона квасца, четири пута више у односу на дотадашњу44.

„Прва Искра наменска а.д.“ Барич произвела је средстава за дезинфекцију на бази персирћетне киселине. Успели су да увезу сировине тако да могу направити више од милион литара дезинфекционог средства 45 .

Фабрика „Панон“ у Црвенки после пет година обновила је производњу алкохола (етил-алкохол у концентрацијама од 96\% и 70\% свакодневно по 30.000 литара). Тренутно је седиште „Панона“ регистровано у Келебији, а фирма је у поступку реорганизације, са пореским дугом од 125 милиона динара. Почетком године

43 Јелица Антељ и Ивана Албуновић, „Да ли ће од маја бити довољно хране“, Политика, 31.03.2020, http://www.politika.rs/scc/clanak/451279/Da-li-ce-od-maja-biti-dovoljnohrane, 29/08/2020.

44 „Учетворостручена производња квасца у фабрици у Сенти“, Енергетски портал, 26. март .2020, https://www.energetskiportal.rs/ucetvrostrucena-proizvodnja-kvasca-u-fabrici-usenti/, 30/08/2020.

45 М. Г, „Одбрамбена индустрија произвела средство за дезинфекцију“, Политика, 20. март .2020, http://www.politika.rs/scc/clanak/450432/Odbrambena-industrija-proizvelasredstvo-za-dezinfekciju-FOTO, 30/08/2020. 
закупац је постала „Лион група“ из Суботице, која је заинтересована за куповину црвеначке „Шпиритане“46.

У Црвенки се започела производња натријум-хипохлорита за комуналну хигијену у фирми „Сигма“, а слично је урађено и у Сремској Митровици, Новом Саду и Бајмоку, где је такође произвођен натријум хипо-хлорид, који је дезинфекционо средство за подове, равне и отворене површине у количини од пет тона концентрата, односно 50.000 литара дезинфекционог средства 47.

У Суботици, Новом Пазару, Трстенику, Пожаревцу и на још неким местима су се шиле маске ${ }^{48}$. У процес производње су се укључивали и волонтери, факултети, власници ЗД штампача и други (нпр. Фејсбук група Визионари Србије). За производњу маски стигла је и машина из Кине.

Индустријска производња уопште смањена је за 16,6\% у односу на 2020, чему је посебно допринео пад у прерађивачкој индустрији. Производња аутомобила, једног од главних српских извозних производа, пала је за 50\%.49 Порасла је производња фармацеутских производа и препарата, док је пала производња у металској индустрији. Остале индустрије нису имале пад. Истовремено рударска производња остала је готово иста ${ }^{50}$.

Од почетка године извоз је био вредан 5,24 милијарде евра, и мањи је за 5\% у поређењу са истим периодом 2019, а увоз је „тежио“ 7,4 милијарди, што је смањење од 1,7\% на годишњем нивоу 51.

Комисија за контролу државне помоћи одобрила је давање бесповратних средстава од 14,4 милиона евра за компанији „Хенкел“ за инвестицију од 93,5 милиона евра за изградњу нове производне линије и проширење капацитета фабрике кућне хемије у Крушевцу. Уколико је ова линија намењена производњи која до сада није била у Србији, ова подстицајна мера ће донети

46 3. Рајић, „Обновили производњу алкохола: "Панон" оживео усред епидемије“, Новости, 13. мај 2020, https://www.novosti.rs/vesti/srbija.73.html:864449-Obnovili-proizvodnjualkohola-Panon-oziveo-usred-epidemije, 30/08/2020.

47 „У Суботици почела производња средстава за дезинфекцију, а у Новом Пазару маски“,Политика, 23. март 2020, http://www.politika.rs/scc/clanak/450515/U-Suboticipocela-proizvodnja-sccedstava-za-dezinfekciju-a-u-Novom-Pazaru-maski\#!, 31/08/2020.

48 С.Б, „Кројачи шију маске у Трстенику и Пожаревцу“, Новости, 21. март . 2020, https://www.novosti.rs/vesti/srbija.73.html:854341-Krojaci-siju-maske-u-Trsteniku-iPozarevcu, 31/08/2020.

49 „Производња у аутоиндустрији Србије преполовљена због короне“, Политика, 20. јун .2020, http://www.politika.rs/scc/clanak/456630/Proizvodnja-u-autoindustriji-Srbijeprepolovljena-zbog-korone, 31/08/2020.

50 https://www.stat.gov.rs/media/5239/industrijska-proizvodnja.pdf

51 „Спољнотрговинска робна размена, за текући период и април 2020.“, Републички завод за статистику, 29. мај 2020, https://www.stat.gov.rs/sr-Cyrl/vesti/20200529spoljnotrgovinska-robna-razmena-za-tekuci-period-i-april-2020, 31/08/2020. 
вишеструку корист. Управо су детерџенти били дефицитарна роба током санкција у $1990-$ тим $^{52}$.

За регулисање ове области донете су четири уредбе и одлуке којима су се ограничавале цене у малопродаји, изменили неки технички захтеви и стандарди и забранио извоз лекова.

\section{Инбормационо-комуникациони ресурси ${ }^{53}$}

У Србији је тренутно активно око 120 ТВ станица и око 250 радио-станица. То практично значи да свака општина има сопствену радио-станицу, а две трећине имају и ТВ станицу. Дисперзија информација преко великог броја радио и ТВ станица даје потенцијал флексибилности домаћем информативном сервису. Истовремено, локална средства масовног информисања имају велику улогу у обавештавању локалних заједница о ситуацији и потенцијалним опасностима карактеристичним за ужу средину. Претходном треба додати податак да 64,5\% Срба има компјутер, а корисника мобилне телефоније има више од 9 милиона, што превазилази укупан број становника Србије. Број интернет претплатника је већи од 6 милиона. ${ }^{54}$.

Из претходног произилази да практично не постоји породица у Србији без телевизора ни појединац без мобилног телефона, што пружа могућност преношења информација до свих грађана. То је коришћено за наставу ђацима основних и средњих школа и барем једанпут слањем упозоравајуће CMC поруке. Ипак, постоји мањак компјутера да би се осигурала настава на даљину путем савремених апликација, јер немају сви компјутер.

Држава би требала да набави таблете за све ђаке и да мерама подстицаја утиче на замену застарелих мобилних телефона да би се омогућила инсталација апликација које би могле да послуже повећању безбедности грађана.

За будућност је вероватно интересантан пример Чешке, где је тестиран тзв. паметни карантин - праћење људи преко коришћења телефона и банкарских картица. Паметни карантин подразумева да се преко података од провајдера мобилне телефоније и са банкарских картица убрзано трасирају контакти људи заражених коронавирусом. „Паметни карантин“ подразумева то да ће уз сагласност зараженог посредством података од провајдера његовог мобилног телефона бити проверавани ГПС локације и на основу плаћања банкарском картицом где све се кретао у последњих пет дана и кога је могао да сретне и

52 „Хенкел“ добија 14.4 милиона евра од државе за проширење производње у Крушевцу, Политика, 04. мај 2020, http://www.politika.rs/scc/clanak/453433/Henkel-dobija-14-4miliona-evra-od-drzave-za-prosirenje-proizvodnje-u-Krusevcu, 01/09/2020.

53 Одговорност телекомуникационе и ИТ службе.

54 Петар Станојевић, Василије Мишковић, Гордана Мишев, Национална логистика и безбедност, op. cit. 
зарази. „Паметни карантин“ организовала је војска, а том мером управљао је шеф националног Централног кризног штаба. За „паметни карантин“ војска је издвојила 253 војника и 82 возила, а генералштаб има епидемиологе, лекаре и своје три болнице 55 . Постоји и супротан пример, Врховни суд Израела забранио је обавештајној агенцији да прати локацију телефона корисника заражених коронавирусом ${ }^{56}$.

\section{Ресурси здравствене заштите 57}

У Србији је закључно са 31. 12. 2017. године било обавезно здравствено осигурано 6.901 .482 грађана, од чега је $1.962 .002^{58}$ пензионера. Према подацима Института за јавно здравље Србије „Др Милан Јовановић - Батут“ „на дан 31. 12. 2018. године је у систему здравствене заштите Републике Србије (здравствене установе у Плану мреже) било запослено укупно 101.498 радника. Здравствених радника и сарадника са високом стручном спремом било је 24.816. Доктора медицине било је 19.984 (81\%), доктора стоматологије 1.607 (6\%), фармацеута 1.653 (7\%) и осталих 1.572 (6\%). Међу докторима медицине било је 5.274 доктора без специјализације (26\%), од тога 2.803 доктора опште медицине (14\%) и 2.471 лекара на специјализацији (12\%). Укупан број лекара специјалиста износио је 14.710 (74\%). Удео жена међу запосленим докторима медицине (65\%) знатно је већи у односу на мушкарце (35\%). Од укупно 1.607 стоматолога у здравственим установама у Републици Србији 840 (52\%) су специјалисти, док је од 1.653 запослених фармацеута њих 308 (19\%) са специјализацијом. У здравственим установама 2018. године било је укупно 10.138 здравствених радника и сарадника са вишом стручном спремом, од чега 5.710 (56\%) медицинских сестара-техничара. Са средњом стручном спремом било је запослено 44.825 здравствених радника и сарадника, од тога 30.982 (69 \%) медицинских сестара-техничара. У здравственим установама било је запослено и 21.517 немедицинских радника, од тога 7.402 (34\%) административних радника и 14.115 (66\%) техничких радника.“"59

55 „Шта је 'паметни карантин' који уводи Чешка“, Б92, 30. март .2020, https://www.b92.net/info/vesti/index.php?yyyy=2020\&mm=03\&dd=30\&nav_category=78\& nav_id=1670981, 01/09/2020.

56 „Врховни суд одлучио - До даљег се обуставља надзор становништва“, $592,28$. април 2020, https://www.b92.net/tehnopolis/vesti.php?yyyy=2020\&mm=04\&nav_id=1678758, 01/09/2020.

57 Одговорност санитетске службе.

58 „Број осигураника“, Републички фонд за здравствено осигурање, https://www.rfzo.rs/index.php/broj-osiguranika-stat, 01/09/2020.

59 Здравствено-статистички годишњак Републике Србије 2018, Институт за Јавно здравље „Др Милан Јовановић Батут“, Београд, 2019,

http://www.batut.org.rs/download/publikacije/pub2018.pdf, стр. 62. 
За остваривање законом утврђених права на болничку здравствену заштиту у Републици Србији предвиђено је 38.611 болничких постеља, односно до 5,5 постеља на 1.000 становника, и то за болничке постеље:

1) краткотрајну хоспитализацију акутно оболелих и повређених:
a) на секундарном нивоу
24.694
б) на терцијарном нивоу
6.000

2) продужено лечење и дуготрајну хоспитализацију:
а) психијатријских болесника
3.250

б) оболелих од туберкулозе, неспецифичних обољења плућа и других хроничних обољења и стања 1.282

3) рехабилитацију у специјализованим болничким установама

Под болничким постељама не подразумевају се постеље у дневним болницама, неонатолошким одељењима породилишта, ни постеље за пратиоца, као ни постеље у стационару дома здравља, заводу за здравствену заштиту студената, завода за геријатрију и палијативно збрињавање, односно постеље у ванболничком породилишту дома здравља ${ }^{60}$.

Према подацима Уредбе о плану мреже здравствених установа за 2020.61 систем здравствене заштите обухвата 366 здравствених установа:

- 161 дом здравља;

- 38 апотека;

- 83 болнице (опште и специјалне);

- 20 института;

- 7 клиника;

- 6 клиничко-болничка центра;

- 4 клиничка центра (Београд, Крагујевац, Ниш, Нови Сад)

- 44 завода (за јавно здравље, судску медицину, трансфузију итд)

- Војномедицинска академија (ВМА) и

- 2 војномедицинске установе.

Нема званичних података новијих од 2018. године. Оно што је евидентно је да се број постеља у државном здравственом систему Србији готово није променио од

60 Ibid.

61 „Уредба о плану мреже здравствених установа (2020)“, Службени гласник РС, бр. 5/2020, 11/2020, 52/2020 и 88/2020, Београд. 
2014. до 2018. године, али се број установа повећао. Укупан број здравствених радника опао је за око 8\% у посматраном периоду ${ }^{62}$.

Србија спада у горњу петину по броју лекара по глави становника. По том броју Србија се налази испред Сједињених Америчких Држава, Румуније, Јапана, Словачке, Хрватске, Пољске, Луксембурга, Ирске и свих других држава некадашње Југославије, али је истовремено иза осталих држава ЕУ и Русије. Највише лекара по глави становника има Куба (160\% више лекара по глави становника од Србије, а у ЕУ Монако има нешто више од $100 \%$ више лекара од Србије)63. Србија има око $50 \%$ више лекара по глави становника од Румуније или Црне Горе.

У приватном сектору функционише 1.020 ординација, 2.000 апотека, 2.500 стоматолошких амбуланти, 200 лабораторија, 155 поликлиника, 18 домова здравља, 12 општих и 76 специјалних болница, као и 5 завода за радиолошку дијагностику. Стални посао у приватном сектору има 4.233 лекара који раде са око 7.000 хонорарних лекара. Могло би се рећи да свака општина у Србији има дом здравља и барем неку ординацију, а да на две-три општине долази једна болница. То би значило да је покривеност територије медицинском заштитом задовољавајућа64.

Расходи за здравствену заштиту у дужем периоду показују релативну стабилност. Издвајања за здравствену заштиту као проценат од бруто домаћег производа (5-10\%) изнад су просека Европске уније и већине европских земаља. Међутим, Република Србија издваја у апсолутном износу мала средства (око 1,8 милијарди евра) за здравствену заштиту у поређењу са другим европским земљама, што је последица релативно ниског нивоа БДП-а 65 .

Тржиште лекова Србије по подацима ИМС за 2015. годину износи око 788 милиона евра. Количински домаћи лекови чине 62\%, а увозни $38 \%$ (у финасијсковредносном смислу ситуација је обрнута). Болничке и државне апотеке дистрибуирају око 52\% укупне количине лекова, остатак се дистрибуира преко приватних апотека. Највећи српски произвођачи лекова су: „Хемофарм“ Вршац, „Здравље“ Лесковац и „Галеника“ Београд (више од 95\% домаће производње). Вредност извоза лекова је преко 212 милиона долара, а увоз око 185 милиона долара66.

Током ванредног стања ова област је регулисана помоћу седам уредби и наредби везаних за проглашење епидемије, забране и ограничења посета и кретања,

\footnotetext{
62 Петар Станојевић, Василије Мишковић, Гордана Мишев, Национална логистика и безбедност, ор. cit.

63 "Health Workforce", World Health Organization, https://www.who.int/gho/health_workforce/physicians_density/en/, 03/09/2020.

64 Петар Станојевић, Василије Мишковић, Гордана Мишев, Национална логистика и безбедност, ор. cit.

65 Ibid.

66 Ibid.
} 
организовању и спровођењу мера карантина и отварању привремених објеката за смештај. Од материјала су набављани респиратори, заштитна опрема и сировине за лекове.

Борба против пандемије показала је да српски здравствени систем има довољно капацитета, односно отпорности, али и флексибилности да се избори са оваквим изазовима. Није дошло до преоптерећења система. Не треба, међутим, изгубити из вида да су капацитети смањени у односу на претходне године. Стање је поправљено већим пријемом младих лекара током епидемије. Дограђен је део ВМЦ у Београду, капацитета 170 постеља.

Интересантно је да капацитети приватног сектора нису готово уопште ангажовани. Једино логичко објашњење за ово лежи у чињеници да се употреба ових ресурса мора надокнадити према тржишним ценама и да се желело избећи излагање додатним трошковима.

\section{Стамбени и смештајни ресурси ${ }^{67}$}

Статистички годишњак Р. Србије за 2016. годину наводи да постоје 834 туристичка смештајна објекта са 43.603 смештајних јединица и 102.940 лежаја68.

Туристички објекти нису коришћени иако су били стављени на располагање Влади. За отварање привремених болница су се углавном користила сајамске хале. Војска је за ове потребе имала довољно намештаја и опреме.

Могло би се закључити да у Србији постоје више него довољни смештајни капацитети за сличне кризне ситуације.

\section{Енергетика и инфраструктура}

Електрична енергија се показала као кључни ресурс током пандемије ковида 19. Да ње није било довољно, не би се могло ни радити ни учити на даљину, ни комуницирати са грађанством, ни наручивати роба, ни задовољавати свакодневне потребе.

Горива је било у изобиљу, а цене су падале због наглог смањења потрошње (и до $40 \%)$ и несугласица највећих светских произвођача нафте. Није било прекида снабдевања гасом.

Србија није имала несташице енергената. Грејна сезона је чак продужена.

Проблема са саобраћајном инфраструктуром није било и саобраћај, иначе смањеног интензитета, несметано се одвијао.

\footnotetext{
67 Одговорност интендантске службе.

68 Петар Станојевић, Василије Мишковић, Гордана Мишев, Национална логистика и безбедност, op. cit.
} 
Најважнија инфраструктура током пандемије је био интернет. „Дигитална агенда“ за Европу предвиђа да до краја 2020. године 100\% становништва ЕУ има широкопојасни приступ интернету (интернет, телефон, ТВ и други сигнали се могу пренети) са брзинама већим од $30 \mathrm{MB} / \mathrm{c}$, а да $50 \%$ популације има приступ врло брзим широкопојасним прикључцима са брзинама 100 МВ/с. У 2015. години 78\% свих домаћинстава у ЕУ имало је широкопојасни приступ интернету, док је тај број у Србији био 56\%. Планови су да се Србија до 2020. године изједначи са ЕУ у смислу широкопојасног приступа интернету. Такође, Србија тежи циљевима које је поставила ЕУ, а којима је предвиђено да брзина интернета буде до 2020. око 100 мегабита у секунди ${ }^{6}$.

Током епидемије, посебно током пробног испита за малу матуру, показали су се недостаци интернет инфраструктуре у Србији: недовољна брзина, проток не покрива целокупну територију земље.

\section{ЗАКЉУЧНЕ НАПОМЕНЕ}

Кризне ситуације са собом носе много неодређености и неизвесности и захтевају брзу реакцију. Потпун и благовремен одговор на све могуће проблеме, ризике и претње није могућ, али је могуће смањити њихове негативне ефекте. У одговору на кризу подједнако су важни отпорност система (првенствено се схвата кроз постојање неопходних снага и средстава) и његова флексибилност (могућност брзог прилагођавања). Ефективнији и ефикаснији одговор на појаве кризних ситуација постиже се кроз скуп припремних радњи које подразумевају проактивну припрему људских и материјалних ресурса, односно управљање превентивним активностима.

Епидемија ковида 19 показала је да су неупоредиво боље прошле земље које имају сопствене прехрамбене капацитете, минимум самодовољности у фармацеутском сектору и монетарни суверенитет.

У последње три деценије Србија је остала без многих производних, али и развојних капацитета. Практично се земља вратила у стање пред ратове 1912-1918. године, када је могла самостално да се прехрани, под условом да има ко да обради земљу, а њени индустријски, здравствени и други ресурси били су ограничени, односно отпорност система је била мала. Тада је решење нађено у стварању залиха и ослањању на увоз од савезника. Практично, то је најреалније решење за повећање отпорности и у данашње време.

У кризи изазваној пандемијом ковида 19 показало се да Србија само делимично може да се ослони на отпорност система. Традиционални ресурси и капацитети (производња хране) и они створени још у Југославији и раније (медицински систем) представљали су и овај пут главни ослонац националног логистичког

69 Ibid. 
система, који је обезбедио да Србија поседује ресурсе везане за основне животне потребе и медицинску заштиту. Оно што је свакако позитивно је брза реакција система, односно исказана флексибилност у набавци свега дефицитарног. Као посебно позитиван моменат требало би издвојити ангажовање и резултате домаћих „интелектуалних ресурса“ у развоју опреме, тестова, па и успостављања или ревитализације производних програма за недостајуће материјале.

Припреме за кризне ситуације у Србији се нису показале свеобухватне. Оно што се свакако не може сматрати позитивним је недостатак резерви потребне опреме и материјала. Овај недостатак није само последица недостатка финансија, већ је и последица недостатака у систему планирања који укључују недостатак координације, недовољно јасну расподелу надлежности и анализу ризика и могућих сценарија.

Неизвесност око тока ширења епидемије и недостатак потребне заштитне опреме, тестова, лабораторијских капацитета и другог (што све представља логистику) условио је примену веома рестриктивних мера за очување здравља код становништва на почетку. Када су ресурси обезбеђени и са довољним капацитетима, то је довело до промене стратегије. Дате су и препоруке којима би се управљање логистичком подршком кризним ситуацијама у Србији могло побољшати, посебно у домену отпорности, али и флексибилности.

Оно што би се могло сматрати препорукама на основу изнетих искустава је да треба: обезбедити чување дела новчаних резерви у земљи, оформити и обучити јединица радне обавезе и цивилне заштите, исправити недостатке у прописима по којима је нејасно да ли је могуће масовно ангажовање јединица радне обавезе без проглашења ванредног стања, размотрити увођење војног рока по швајцарском моделу у складу са концептом „тоталне одбране“, увести садржаје из безбедности у систем образовања, јачати интелектуалне ресурсе, њихове компетенције и капацитете, креирањем одговарајућих прописа спречавати стварања залиха код становништва, подстицати сваковрсну домаћу индустријску и пољопривредну производњу, створити залихе критичних роба према дефинисаним приоритетима, детаљније дефинисати критичне робе и услуге. Такође је потребно и утврђивање и очување ресурса за производњу критичних материјала у складу са законом, јачање интернет инфраструктуре, осавремењавање мобилних телефонских апарата, опремање сваког ђака или студента барем таблетом, креирање безбедносних апликација и законско регулисање њихове примене.

\section{ЛИТЕРАТУРА}

- "Health Workforce", World Health Organization, https://www.who.int/gho/health_workforce/physicians_density/en/. 
- "Serbia Military Strength (2020)", Global Firepower Index, https://www.globalfirepower.com/country-military-strengthdetail.asp?country_id=Serbia.

- „Закон о војној, радној и материјалној обавези (2018)“, Службени гласник РС, бр. 88/2009, 95/2010 и 36/2018, Београд, 10. мај 2018.

- „Успех Српских научника: Направили тест на корону, ради чак и ако ВИРУС МУТИРА“. Блиц, 12. мај. 2020, https://www.blic.rs/vesti/drustvo/uspeh-srpskihnaucnika-napravili-test-na-koronu-radi-cak-i-ako-virus-mutira/7m5mzdm.

- „Број осигураника“, Републички фонд за здравствено осигурање, https://www.rfzo.rs/index.php/broj-osiguranika-stat.

- „Врховни суд одлучио - До даљег се обуставља надзор становништва“, Б92, 28. април 2020, https://www.b92.net/tehnopolis/vesti.php?yyyy=2020\&mm=04\&nav_id=1678758.

- „Девизне резерве Србије 12,79 милијарди евра на крају априла“, Политика, 14. мај .2020, http://www.politika.rs/sr/clanak/454131/Devizne-rezerve-Srbije-12-79milijardi-evra-na-kraju-aprila.

- „Закон о буџету Републике Србије за 2020. годину (2020)“, Службени гласник РС, бр. 84/2019 и 60/2020, Београд, 24. април 2020.

- „Закон о јавним набавкама (2015)“, Службени гласник РС, бр. 68/2015, Београд, 04. август 2015.

- „Закон о одбрани Републике Србије (2018)“ Службени гласник РС, бр. 36/2018, Београд, 10. мај 2018.

- „Овако су Срби куповали први и последњи дан ванредног стања, само за једном намирницом скок 500\%“, InfoBiz, 09. мај 2020, https://biznis.telegraf.rs/infobiz/3187674-neverovatne-cifre-ovako-su-srbi-kupovali-prvi-i-poslednji-danvanrednog-stanja.

- „Одлука о емисији дугорочних државних хартија од вредности, 05 број 4242753/2020“, Службени гласник РС, бр. 39/2020, Београд, 21. март 2020.

- „Одлука о одређивању производа и услуга од посебног значаја за одбрану Републике Србије (2019)“, Службени гласник РС, бр. 58/2008 и бр. 26/2019, Београд, 6. јун 2008. и 5. априла 2019.

- „Представљени резултати јавног позива за сузбијање ефеката пандемије COVID19“, Фонд за иновациону делатност Републике Србије, 18. мај 2020, http://www.inovacionifond.rs/info/predstavljeni-rezultati-javnog-poziva-zasuzbijanje-efekata-pandemije-covid-19.

- „Производња у аутоиндустрији Србије преполовљена због короне“, Политика, 20. јун .2020, http://www.politika.rs/scc/clanak/456630/Proizvodnja-uautoindustriji-Srbije-prepolovljena-zbog-korone.

- „Спољнотрговинска робна размена, за текући период и април 2020.“, Републички завод за статистику, 29. мај 2020, https://www.stat.gov.rs/sr- 
Cyrl/vesti/20200529-spoljnotrgovinska-robna-razmena-za-tekuci-period-i-april2020.

- „Стратегија националне безбедности Републике Србије (2019)“ Службени гласник РС, бр. 94/2019, Београд, 27. децембар 2019.

- „У Данској средство за дезинфекцију 5,5 евра, цена за два комада - 134 евра“, Н1, 21.03.2020, http://rs.n1info.com/Lifestyle/a580493/U-Danskoj-sredstvo-zadezinfekciju-5-5-evra-cena-za-dva-komada-134-evra.html.

- „У Суботици почела производња средстава за дезинфекцију, а у Новом Пазару маски“, Политика, 23. март 2020, http://www.politika.rs/scc/clanak/450515/USubotici-pocela-proizvodnja-sccedstava-za-dezinfekciju-a-u-Novom-Pazaru-maski\#!.

- „У Хрватској обавезни војни рок по швајцарском моделу?“, Политика, 17. април .2020, http://www.politika.rs/scc/clanak/452436/U-Hrvatskoj-obavezni-vojni-rokpo-svajcarskom-modelu.

- „Уредба о коришћењу финансијских средстава буџета Републике Србије за време ванредног стања насталог услед болести цовид-19 изазване вирусом Сарс-Цов-2 (2020)“,Службени гласник РС, бр. 38/2020, Београд, 21. март 2020.

- „Уредба о плану мреже здравствених установа (2020)“, Службени гласник РС, бр. $5 / 2020,11 / 2020,52 / 2020$ и 88/2020, Београд.

- „Учетворостручена производња квасца у фабрици у Сенти“, Енергетски портал, 26. март. 2020, https://www.energetskiportal.rs/ucetvrostrucena-proizvodnjakvasca-u-fabrici-u-senti/.

- „Хенкел“ добија 14.4 милиона евра од државе за проширење производње у Крушевцу, Политика, 04. мај 2020, http://www.politika.rs/scc/clanak/453433/Henkel-dobija-14-4-miliona-evra-oddrzave-za-prosirenje-proizvodnje-u-Krusevcu.

- „Шта је 'паметни карантин' који уводи Чешка“, Б92, 30. март .2020, https://www.b92.net/info/vesti/index.php?yyyy=2020\&mm=03\&dd=30\&nav_catego ry=78\&nav_id=1670981.

- Eccles, Henry E.Logistics in the National Defence. The Stackpole Co, Harrisburg, 1959.

- Stanojević, Petar, Mišković, Vasilije, Jeftić, Zoran. “Overview of elements of national logistics system in the republic of Serbia". Vojno delo, Vol. 69, No. 4, 2017, pp. 96-120.

- А. М. „Мали: Апсолутно смо ликвидни, НЕМА ПРОБЛЕМА за плате и пензије“, Блиц, 12.03.2020, https://www.blic.rs/biznis/vesti/mali-apsolutno-smo-likvidninema-problema-za-plate-i-penzije/g26dk96.

- Антељ, Јелица, и Албуновић, Ивана. „Да ли ће од маја бити довољно хране“, Политика, 31.03.2020, http://www.politika.rs/scc/clanak/451279/Da-li-ce-od-majabiti-dovoljno-hrane.

- Б. С. „Кројачи шију маске у Трстенику и Пожаревцу“, Новости, 21. март .2020, https://www.novosti.rs/vesti/srbija.73.html:854341-Krojaci-siju-maske-u-Trstenikui-Pozarevcu. 
- Г. М. „Одбрамбена индустрија произвела средство за дезинфекцију“, Политика, 20. март. 2020, http://www.politika.rs/scc/clanak/450432/Odbrambena-industrijaproizvela-sredstvo-za-dezinfekciju-FOTO.

- Галовић, Милан. „Војни резервисти у борби против ковида 19“, Политика, 03. април .2020, http://www.politika.rs/scc/clanak/451490/Vojni-rezervisti-u-borbiprotiv-kovida-19.

- Галовић, Милан. „Повратак народне одбране“, Политика, 23. март. 2020, http://www.politika.rs/sr/clanak/450604/\%D0\%9F\%D0\%BE\%D0\%B2\%D1\%80\%D 0\%B0\%D1\%82\%D0\%B0\%D0\%BA\%D0\%BD\%D0\%B0\%D1\%80\%D0\%BE\%D0\%B4\%D0\%BD\%D0\%B5\%D0\%BE\%D0\%B4\%D0\%B1\%D1\%80\%D0\%B0\%D0\%BD\%D0\%B5.

- Здравствено-статистички годишњак Републике Србије 2018, Институт за Јавно здравље „Др Милан Јовановић Батут“, Београд, 2019, http://www.batut.org.rs/download/publikacije/pub2018.pdf,

- Милановић, Озрен. „Нова листа системски значајних банака“, Политика, 17.05.2020, http://www.politika.rs/sr/clanak/454296/Nova-lista-sistemskiznacajnih-banaka.

- Николић, Марко. „Српски хероји направили респиратор вреднији од злата“, Спутњик, 24. мај .2020, https://rs.sputniknews.com/radio_tehnogram/202005241122640224-srpski-herojinapravili-respirator-vredniji-od-zlata-video/.

- Поповић, Небојша. „Корона показала зашто економском моделу Црне Горе истиче рок трајања“, Спутњик 04. април 2020, https://rs.sputniknews.com/regioni/202004041122243909-korona-pokazala-zastoekonomskom-modelu-crne-gore-istice-rok-trajanja- $/$.

- Рајић, 3. „Обновили производњу алкохола: „Панон“ оживео усред епидемије“, Новости, 13. мај 2020, https://www.novosti.rs/vesti/srbija.73.html:864449Obnovili-proizvodnju-alkohola-Panon-oziveo-usred-epidemije.

- Станојевић, Петар, Мишковић, Василије, Мишев, Гордана. Национална логистика и безбедност. Универзитет у Београду - Факултет безбедности, Београд, 2017.

\title{
SOME ASPECTS OF RESILIENCE AND FLEXIBILITY OF THE NATIONAL LOGISTICS RESPONSE TO THE CRISIS CAUSED BY COVID-19 PANDEMIC
}

\begin{abstract}
Crisis situations bring with them a lot of uncertainty and require a quick reaction. A complete and timely response to all possible problems, risks and threats is not possible, but it is possible to reduce their negative effects. In response to the crisis, the resilience of the system is important (primarily understood through the
\end{abstract}


existence of the necessary forces and means, ie resources), as well as its flexibility (possibility of quick adjustment). A more effective and efficient response to the occurrence of crisis situations can be achieved through a set of preparatory actions that include proactive preparation of human and material resources, ie management of preventive activities. The paper deals with the aspects of crisis response based on performance of individual logistics functions. The obvious shortcomings of the national logistics system are mentioned. It turned out that Serbia can supply itself with basic living needs on its own. Preparations for crisis situations in Serbia are not systematic and comprehensive. The positive aspects are primarily related to flexibility and improvisation. The flexibility of the system was at the high level and the shortcomings were quickly compensated. It has become clear that Serbia must decide to increase reserves and stocks as the main source of supply in crisis situations. When certain resources were obtained, this led to a change in strategy. Recommendations were also given by which the management of logistical support to crisis situations in Serbia could be improved, especially in the field of resilience, but also flexibility.

Keywords: crisis situation, national logistics, logistics functions, logistics resources, resilience, elasticity 